\title{
ANALISIS PENGARUH PENGGUNAAN ABU SABUT KELAPA SEBAGAI FILLER PADA CAMPURAN ASPAL RETONA BLEND 55
}

\author{
Meylis Safriani ${ }^{1}$, Dian Febrianti ${ }^{2}$ \\ ${ }^{1,2}$,Jurusan Teknik Sipil Universitas Teuku Umar, Alue Penyareng, Meulaboh, Aceh Barat \\ e-mail: ${ }^{1}$ Mey2_saza@yahoo.com
}

\begin{abstract}
Transport infrastructure is one element of the regional development is indispensable for the smooth access to the existing facilities in the region. The material used in the construction of highways, among others, aggregates, asphalt and filler. During this time the filler material that is often used in asphalt mixtures are cement, lime, stone dust, fly ash. However, these filler materials inventory is limited and relatively expensive. Accordingly, the need to find alternative cheap and easily obtained. One alternative is the utilization of local natural resources. The ash of coconut fiber can not be used anymore and are usually thrown away by society. By using the principles of reuse, recycle and recovery, coconut husk ash is expected to be recovered thus reducing the waste bin. The purpose of this study was to determine the effect of the use of coconut husk ash as filler to mix asphalt Retona Blend 55 and to find out the coconut husk ash can be used as a substitute for the filler material mixture highway or not. The method in this study using laboratory experiments. The research showed that most of the physical properties meet the requirements prescribed specifications. Examination of the physical nature of asphalt Retona Blend 55 which includes examination density, penetration, ductility, and the softening point indicates that the asphalt can be used for fulfilling the requirements set. The composition of the mixture that the best results are with the composition of the mixture by using coconut husk ash as filler by $4.5 \%$ with the optimum asphalt at $6.25 \%$. The use of optimum asphalt of $6.25 \%$ resulted in a value of $1295.47 \mathrm{~kg}$ stability, flow plastically $4.0 \mathrm{~mm}, \mathrm{MQ} 328.51 \mathrm{~kg}$, density of $2.21 \mathrm{~g}$ $1 \mathrm{~cm}^{3}$, VIM 5.43\%, $17.89 \%$ VMA, VFB 70.17\%. Those values have been in accordance with the standard specifications of the Department of Public Works.
\end{abstract}

Keywords: filler, coconut husk ash, Retona Blend 55, mixture of asphalt

\section{PENDAHULUAN}

$\mathrm{J}_{\mathrm{e} h \sin }^{\mathrm{a}}$ lan raya merupakan prasarana transportasi yang berperan strategis dalam bidang sosial, ekonomi, dan budaya. Prasarana transportasi merupakan salah satu unsur pengembangan wilayah yang sangat diperlukan demi kelancaran akses sarana yang ada pada suatu wilayah. Bertambahnya penduduk menjadikan pertumbuhan volume lalu lintas meningkat sehingga kebutuhan jalan juga semakin meningkat. Material yang digunakan dalam pembangunan jalan raya antara lain agregat, aspal, dan bahan pengisi (filler).

Menurut [1], agregat secara umum didefinisikan bahwa agregat sebagai suatu bahan yang terdiri dari mineral, berupa masa yang berukuran besar ataupun berupa fragmen-fragmen. Agregat merupakan komponen utama dari lapisan perkerasan jalan dimana perkerasan jalan mengandung 90\%-95\% agregat berdasarkan persentase berat, 75\%-85\% agregat berdasarkan persentase volume. Menurut [4] aspal adalah material yang pada temperatur ruang berbentuk padat sampai agak padat, dan bersifat termoplastis. Jadi aspal akan mencair jika dipanaskan sampai temperatur tertentu, dan kembali membeku jika temperatur turun. Bersama dengan agregat, aspal merupakan material pembentuk campuran perkerasan jalan. Banyaknya aspal dalam campuran perkerasan berkisar antara $4-10 \%$ berdasarkan berat campuran, atau $10-15 \%$ berdasarkan volume campuran. Penggunaan bahan pengisi dalam campuran beton aspal akan mempengaruhi karakteristik beton aspal. Bahan filler dapat berupa debu batu, kapur, semen, abu terbang, abu tanur semen atau bahan non plastis lainnya [7]. Selama ini material filler yang sering dipakai pada campuran aspal adalah semen, kapur, abu batu, abu terbang/fly ash. Namun, persediaan bahan filler ini terbatas dan juga relatif mahal. Berdasarkan hal tersebut, perlu ditemukan alternatif yang murah dan mudah 
didapatkan untuk menggantikan material filler dari semen, kapur, abu terbang, dan abu batu yang selama ini banyak dipakai sebagai bahan campuran aspal. Salah satu alternatifnya adalah dengan pemanfaatan potensi sumber daya alam daerah setempat. Pemanfaatan tersebut antara lain dengan menggunakan filler dari abu sabut kelapa.

Kelapa telah ditanam hampir di seluruh Indonesia dan luas arealnya terus meningkat. Pada tahun 2004, luas areal perkebunan kelapa yaitu 3.334.000 ha. Tahun 2013, luas perkebunan kelapa di Indonesia 3.654.478. Sejak tahun 1988 Indonesia menduduki urutan pertama sebagai negara yang memiliki areal kebun kelapa terluas di dunia. Dari seluruh luas areal perkebunan kelapa, sekitar 97,4 \% dikelola oleh perkebunan rakyat yang melibatkan sekitar 3,1 juta keluarga petani, sisanya sebanyak $2,1 \%$ dikelola perkebunan besar swasta dan $0,5 \%$ dikelola perkebunan besar negara [6].

Aceh merupakan provinsi penghasil kelapa yang potensial di Indonesia sehingga kelapa merupakan salah satu sumber daya alam yang baik di Aceh. Luas lahan hasil perkebunan kelapa di Aceh mencapai 110.000 ha dengan total produksi 120.000 ton per tahun [2]. Berdasarkan data [4], luas areal perkebunan kelapa di Aceh setiap tahun meningkat. Pada tahun 2014, luas perkebunan dengan total area 103.341 ha menghasilkan produksi kelapa 55.434 ton. dengan jumlah petani 149.141. Pada tahun 2014, luas perkebunan dengan total area 103.938 ha menghasilkan produksi kelapa 55.706 ton dengan jumlah petani 148.264. Dan pada tahun 2015, luas perkebunan dengan total 104.263 ha dan produksinya 56.124 ton.

Hampir semua bagian dari pohon kelapa dapat dipergunakan, seperti daun, batang, buah, dan akarnya. Kulit kelapa yang telah dikupas disebut dengan sabut kelapa, juga merupakan bagian dari kelapa. Masyarakat Aceh terutama yang tinggal di pedesaan biasanya hanya menggunakan sabut kelapa sebagai bahan untuk membuat tali, mencuci piring, dan menggunakan sebagai bahan bakar untuk memasak air, masakan/ kue tradisional, atau memasak nasi. Abu hasil pembakaran dari sabut kelapa tidak dapat dipergunakan lagi dan biasanya dibuang begitu saja oleh masyarakat. Dengan menggunakan prinsip reuse, recycle dan recovery, abu sabut kelapa diharapkan dapat dimanfaatkan kembali sehingga mengurangi limbah sampah.

Penelitian terkait penggunaan substitusi filler pada campuran aspal pernah dilakukan. Penelitian tersebut tentang tinjauan penggunaan serbuk arang tempurung kelapa sebagai filler terhadap karakteristik Laston Lapis Aus (AC-WC). Hasil penelitiannya menunjukkan bahwa penggunaan filler dari 1\% serbuk arang tempurung kelapa ditambah $1 \%$ abu sekam ditambah $5 \%$ abu batu dalam campuran AC-WC menunjukkan kinerja campuran aspal yang paling baik [8]. Dalam penelitian ini, abu sabut kelapa akan digunakan sebagai filler, dan campuran aspal yang digunakan adalah campuran aspal Retona Blend 55. Penelitian ini dilakukan bertujuan untuk mengetahui pengaruh penggunaan abu sabut kelapa terhadap campuran aspal Retona Blend 55 dan untuk mengetahui abu sabut kelapa dapat digunakan sebagai pengganti filler pada campuran material jalan raya atau tidak. Analisa parameter marshall meliputi kepadatan, Voids in Mix (VMA), voids in the mineral aggregate (VMA), voids filled by bitumen (VFB), stabilitas, flow dan marshall quentient.

\section{METODE PENELITIAN}

Penelitian ini dilakukan dengan metode uji laboratorium dengan benda uji yang dibuat dari tiga kelompok. Benda uji pada kelompok pertama dengan menggunakan $4 \%$ abu sabut kelapa sebagai filler, benda uji kedua menggunakan $4,5 \%$ abu sabut kelapa sebagai filler, $\mathrm{d}$ a $\mathrm{n}$ benda uji ketiga menggunakan 5\% sebagai filler. Penelitian dilakukan di Laboratorium Transportasi Jurusan Teknik Sipil Fakultas Teknik Universitas Syiah Kuala. 


\section{Persiapan Material}

Material yang digunakan dalam penelitian ini terdiri dari agregat halus, filler dan aspal. Abu sabut kelapa yang dijadikan sebagai filler diambil dari perumahan masyarakat di Desa Lambaro Angan, Kabupaten Aceh Besar. Aspal Retona Blend 55 diambil dari Dinas PU Bina Marga Banda Aceh. Sebelum pembuatan benda uji dilakukan, terlebih dahulu dilakukan pemilihan dan persiapan material yang diuji berdasarkan standar-standar pengujian dari Bina Marga, AASHTO, ASTM, dan SNI.

\section{Pemeriksaan Material}

Pemeriksaan material terdiri dari pemeriksaan gradasi agregat dan pemeriksaan aspal. Pemeriksaan sifat - sifat fisis agregat yang perlu dilakukan yaitu pemeriksaan berat jenis dan penyerapan agregat, pemeriksaan berat isi agregat, pemeriksaan keausan agregat, pemeriksaan indeks kepipihan dan kelonjongan, dan pemeriksaan tumbukan. Pemeriksaan terhadap aspal terdiri dari pemeriksaan berat jenis aspal, pemeriksaan titik lembek, pemeriksaan penetrasi, dan pemeriksaan daktilitas.

\section{Pemeriksaan sifat - sifat fisis agregat}

Pemeriksaan berat jenis dan penyerapan agregat dilakukan untuk menentukan berat jenis (bulk specific gravity), berat jenis kering permukaan jenuh (saturated surface dry), berat jenis semu (specific gravity apparent) dan penyerapan (absorption). Benda uji yang digunakan adalah agregat yang lolos saringan 3/8" dan tertahan saringan No. 4 sebanyak 5000 gram dan dicuci untuk menghilangkan debu atau bahan-bahan lain yang melekat pada permukaan. Pemeriksaan berat isi agregat dilakukan untuk mengetahui perbandingan berat agregat di dalam wadah dengan volume wadah. Peralatan yang digunakan yaitu wadah baja berbentuk silinder dengan diameter 149,6 mm, tinggi $175 \mathrm{~mm}$ dan tebal dasar pemadat $5,08 \mathrm{~mm}$, tongkat pemadat berdiameter $15 \mathrm{~mm}$ dengan panjang $60 \mathrm{~cm}$ serta timbangan dengan ketelitian 0,1\%. Agregat yang digunakan adalah agregat yang lolos saringan 13,5 $\mathrm{mm}$ dan tertahan saringan $1,36 \mathrm{~mm}$ sebanyak 5000 gram dan dioven pada suhu $110^{\circ} \mathrm{C}$ hingga mencapai berat tetap. Pemeriksaan keausan agregat dilakukan untuk mengetahui ketahanan agregat terhadap keausan dengan menggunakan mesin Los Angeles. Keausan tersebut dinyatakan dengan perbandingan antara bahan yang aus yaitu lewat saringan No. 12 terhadap berat semula dalam persen. Pemeriksaan indeks kepipihan dan kelonjongan dilakukan untuk mengetahui persentase jumlah butir pipih dan butir lonjong yang terdapat dalam satu benda uji dibandingkan dengan berat totalnya. Peralatan yang digunakan untuk mengukur indeks kelonjongan adalah Elongation Gauge, alat ini mempunyai panjang $365 \mathrm{~mm}$, lebar $78 \mathrm{~mm}$, tebal 70 $\mathrm{mm}$ dan berat 1000 gram. Agregat yang digunakan adalah agregat kering oven sebanyak 4000 gram yang diambil secara acak. Pemeriksaan tumbukan dilakukan untuk mengetahui nilai kekerasan agregat melalui tumbukan dengan menggunakan alat impact. Agregat yang digunakan adalah agregat lolos saringan $12,7 \mathrm{~mm}$ dan tertahan saringan $9,25 \mathrm{~mm}$ sebanyak 1000 gram untuk satu benda uji.

\section{Pemeriksaan terhadap aspal}

Pemeriksaan berat jenis aspal dilakukan untuk mengetahui berat jenis aspal keras dengan menggunakan piknometer. Berat jenis aspal adalah perbandingan berat volume aspal dengan berat volume air suling dengan isi yang sama pada suhu $25^{\circ} \mathrm{C}$. Peralatan yang digunakan adalah piknometer, bak perendam yang dilengkapi dengan pengatur suhu dengan ketelitian $(25 \pm 0,1)^{\circ} \mathrm{C}$, bejana gelas, termometer, dan air suling sebanyak $1000 \mathrm{~cm}^{3}$ ditimbang dengan ketelitian 0,1 gram. 
Pemeriksaan penetrasi dilakukan untuk mengetahui angka penetrasi yang sesungguhnya dari aspal yang digunakan dengan memasukkan jarum penetrasi ukuran, beban, suhu dan waktu tertentu kedalam wadah benda uji yang terisi aspal. Pemeriksaan titik lembek dilakukan untuk mengetahui pada suhu berapa aspal yang digunakan akan meleleh sehingga dapat melapisi agregat dengan baik. Peralatan yang digunakan yaitu cincin kuningan, bola baja, dudukan benda uji, bejana gelas, thermometer, penjepit dan alat pengarah bola. Pemeriksaan daktilitas dilakukan untuk mengetahui jarak terpanjang yang dapat ditarik di antara dua cetakan berisi aspal pada suhu, ketebalan, dan kecepatan tertentu untuk menunjukkan kegetasan aspal. Selama percobaan berlangsung benda uji terendam sekurang - kurangnya 2,5 cm dari permukaan air dan suhu harus dipertahankan tetap.

\section{Pengujian Material}

Aspal yang digunakan dalam penelitian ini adalah aspal Retona Blend 55 yang diproduksi oleh PT. Olah Bumi Mandiri. Dipilihnya aspal Retona Blend 55 karena pertimbangan deposit yang sangat besar di Indonesia dan mampu meningkatkan kestabilan, ketahanan fatigue dan keretakan akibat temperatur. Retona Blend 55 yang digunakan untuk bahan penyusun konstruksi perkerasan jalan harus memenuhi syarat seperti pada Tabel 1 berikut ini.

Tabel 1 Karakteristik Retona Blend 55

\begin{tabular}{|c|l|c|c|}
\hline No & \multicolumn{1}{|c|}{ Jenis Pengujian } & Metoda Pengujian & Karakteristik Retona \\
\hline 1 & Penetrasi pada $25^{0} \mathrm{C}$ & SNI 06-2456-1991 & $40-55$ \\
\hline 2 & Berat Jenis & SNI-06-2441-1991 & $\geq 1,0$ \\
\hline 3 & Titik Lembek $\left({ }^{0} \mathrm{C}\right)$ & SNI 06-2434-1991 & $>55$ \\
\hline 4 & Kelekatan agregat terhadap retona $\%$ & SNI 03-2439-1991 & $>95$ \\
\hline
\end{tabular}

Bahan pengisi yang ditambahkan pada campuran aspal harus kering dan bebas dari gumpalangumpalan dan bila diuji dengan pengayakan sesuai SNI 03-1968-1990 harus mengandung bahan lolos ayakan No. 200 (75 micron) tidak kurang dari 75\% terhadap beratnya. Bahan pengisi yang akan digunakan penelitian ini yaitu abu sabut kelapa yang lolos saringan No. 200 (0,074 mm).

\section{Pemilihan Gradasi Agregat Untuk Campuran}

Kurva gradasi yang digunakan dalam penelitian ini adalah gradasi AC-WC dengan penyesuaian mendekati gradasi lengkung Fuller Type V. Agregat yang digunakan dalam penelitian ini tidak dapat langsung digunakan dalam penelitian karena gradasi alam belum tentu sesuai dengan gradasi yang digunakan. Gradasi yang digunakan dalam penelitian ini adalah gradasi menerus. Pemeriksaan gradasi dilakukan dengan analisa saringan. Agregat diayak menggunakan satu set saringan yang ada sesuai dengan ukuran yang dibutuhkan, ditampilkan pada Tabel 1 sebagai berikut.

Tabel 1 Rancangan Gradasi Agregat

\begin{tabular}{|c|c|c|c|c|c|c|}
\hline \multicolumn{2}{|c|}{ Ukuran Ayakan } & \multicolumn{3}{c|}{ \% Berat yang Lolos } & \multicolumn{2}{c|}{$\begin{array}{c}\text { \% Berat yang } \\
\text { Tertahan }\end{array}$} \\
\hline ASTM & $(\mathrm{mm})$ & Spesifikasi & $\begin{array}{c}\text { Fuller } \\
\text { Type V }\end{array}$ & $\begin{array}{c}\text { Gradasi } \\
\text { Uji } \\
\text { Rencana }\end{array}$ & Tertahan & Kumulatif \\
\hline $1 "$ & 25 & & & & & \\
\hline $3 / 4 "$ & 19 & 100 & 100 & 100 & & \\
\hline $1 / 2 "$ & 12,5 & $90-100$ & 83 & 85 & 15 & 15 \\
\hline
\end{tabular}




\begin{tabular}{|c|c|c|c|c|c|c|}
\hline $3 / 8$ & 9,5 & Maks. 90 & 73 & 70 & 15 & 30 \\
\hline No.4 & 4,75 & & 54 & 50 & 20 & 50 \\
\hline No.8 & 2,36 & $28-58$ & 39 & 35 & 15 & 65 \\
\hline No.16 & 1,18 & & 29 & 24 & 11 & 76 \\
\hline No.30 & 0,6 & & 21 & 18 & 6 & 82 \\
\hline No.50 & 0,3 & & 15 & 13 & 5 & 87 \\
\hline No.200 & 0,075 & $4-10$ & 8 & 5 & 8 & 95 \\
\hline PAN & 0 & 0 & 0 & 0 & 5 & 100 \\
\hline \multicolumn{7}{|c|}{ DAERAH LARANGAN } \\
\hline No. 4 & 4,75 & & & & & \\
\hline No.8 & 2,36 & 39,1 & & 35 & & \\
\hline No. 16 & 1,18 & $25,6-31,6$ & & 24 & & \\
\hline No. 30 & 0,600 & $19,1-23,1$ & & 18 & & \\
\hline No. 50 & 0,300 & 15,5 & & 13 & & \\
\hline
\end{tabular}

\section{Perencanaan Campuran Dengan Metode Marshall}

Nilai Kadar Aspal Optimum (KAO) diperoleh dengan Metode Marshall. Pada pengujian dengan alat Marshall, hal pertama dilakukan adalah menghitung perkiraan awal Kadar Aspal Tengah $\left(\mathrm{P}_{\mathrm{b}}\right)$. Dengan terlebih dahulu membulatkan nilai $\mathrm{P}_{\mathrm{b}}$ sampai $0,5 \%$ terdekat, kemudian menyiapkan benda uji Marshall pada 5 variasi kadar aspal masing-masing 3 (tiga) benda uji, yaitu $-1,0 \%,-0,5 \%, \mathrm{~Pb} \%$ (perkiraan Kadar Aspal Tengah), $+0,5 \%$ dan $+1,0 \%$ terhadap berat total campuran. Benda uji yang digunakan adalah benda uji standar berbentuk tabung dengan diameter $102 \mathrm{~mm}$ (4 inch) dan tinggi 63,5 mm (2,5 inch). Pemadatan untuk uji Marshall dilakukan dengan penumbukan sebanyak 75 kali per bidang dengan menggunakan penumbuk Marshall. Setelah benda uji dipadatkan, kemudian disimpan pada suhu ruang selama 24 jam, selanjutnya benda uji ditimbang di udara, didalam air dan dalam kondisi kering-permukaan jenuh (Saturated Surface Dry, SSD) untuk mendapatkan berat jenis bulk (Bulk Specific Gravity). Selanjutnya direndam pada temperatur $60{ }^{\circ} \mathrm{C}$ selama 30 menit dan siap untuk pengujian stabilitas dan flow.

Setelah nilai stablitas dan flow didapat, kemudian dihitung besarnya hasil bagi Marshall (Marshall Quotient), rongga diantara mineral agregat (VMA), rongga dalam campuran (VIM), dan rongga terisi aspal (VFB). Selanjutnya digambarkan grafik hubungan antara kadar aspal (\%) dengan masing-masing parameter Marshall yang telah dihitung sebelumnya. Dengan melihat pada batas-batas yang disyaratkan untuk semua parameter Marshall (Stabilitas, Flow, MQ, VFB, VMA, VIM dan VIM), maka ditentukan besarnya KAO sehingga memenuhi semua kriteria. Setelah didapat KAO dari penggunaan aspal Retona Blend 55, maka dibuat masing masing 3 benda uji. Banyaknya benda uji untuk mengetahui sifat-sifat campuran dan penentuan kadar aspal masing-masing campuran dapat disajikan pada Tabel 2.

Tabel 2 Jumlah Benda Uji untuk Metode Marshall menggunakan Abu Sabut Kelapa sebagai Filler

\begin{tabular}{|c|c|c|}
\hline \multirow{2}{*}{ No. } & \multirow{2}{*}{ Kadar Aspal } & Jumlah \\
\hline & & Retona Blend 55 \\
\hline 1. & $\mathrm{P}_{\mathrm{b}}-1,0$ & 3 Buah \\
\hline 2. & $\overline{P_{b}-0,5}$ & 3 Buah \\
\hline 3. & $\mathrm{P}_{\mathrm{b}}$ & 3 Buah \\
\hline 4. & $\mathrm{P}_{\mathrm{b}}+0,5$ & 3 Buah \\
\hline 5. & $\mathrm{P}_{\mathrm{b}}+1,0$ & 3 Buah \\
\hline & Total & 15 Buah \\
\hline
\end{tabular}




\section{HASIL DAN PEMBAHASAN}

\section{Hasil Pemeriksaan Sifat-sifat Fisis Agregat}

Berdasarkan data hasil pemeriksaan laboratorium terhadap sifat-sifat fisis agregat diperoleh bahwa sebagian besar sifat fisis tersebut telah memenuhi persyaratan spesifikasi yang ditentukan, kecuali indeks kelonjongan dan kepipihan tidak dapat memenuhi spesifikasi, yaitu maksimal $10 \%$. Tetapi di dalam spesifikasi pada uraian tentang agregat kasar terdapat ketentuan yang menyatakan apabila terdapat ketidak sesuaian, nilai tersebut dapat ditolerir, apabila agregat tersebut memenuhi semua ketentuan lainya. Terutama apabila hasil dari pengujian Abrasi dengan mesin Los Angeles memenuhi syarat. Hasil pemeriksaan sifat fisis agregat ditampilkan pada Tabel 3.

Tabel 3 Hasil Pemeriksaan Sifat-sifat Fisis Agregat

\begin{tabular}{|l|l|c|c|c|}
\hline No. & \multicolumn{1}{|c|}{ Sifat-sifat Fisis yang Diperiksa } & Satuan & Hasil & Persyaratan \\
\hline 1. & Berat jenis & gr/cm3 & 2.515 & Min. 2.5 \\
\hline 2. & Penyerapan & $\%$ & 1,321 & Min. 3 \\
\hline 3. & Berat isi & Kg/dm3 & 1,459 & Min.1 \\
\hline 4. & Kekerasan & $\%$ & 14,13 & Mak.30 \\
\hline 5. & Keausan & $\%$ & 30,3 & Mak. 40 \\
\hline 6. & Indeks Kepipihan & $\%$ & 18,04 & Mak.10 \\
\hline 7. & Indeks Kelonjongan & $\%$ & 12,40 & Mak. 10 \\
\hline 8. & Kelekatan Agregat Terhadap Aspal & 97 & Min. 95 \\
\hline
\end{tabular}

\section{Hasil pemeriksaan sifat-sifat fisis aspal}

Pemeriksaan sifat-sifat fisis aspal Retona Blend 55 meliputi pemeriksaan berat jenis, penetrasi, daktilitas, dan titik lembek. Berdasarkan data hasil pemeriksaan sifat-sifat fisis aspal Retona Blend 55 memperlihatkan bahwa aspal tersebut dapat digunakan karena memenuhi persyaratan yang ditetapkan. Hasil pemeriksaan sifat-sifat fisis aspal Retona Blend 55 disajikan pada Tabel 4 berikut.

Tabel 4 Hasil Pemeriksaan Sifat-sifat Fisis Aspal Retona Blend 55

\begin{tabular}{|l|l|c|c|c|}
\hline No. & \multicolumn{1}{|c|}{$\begin{array}{c}\text { Sifat-sifat Fisis Aspal } \\
\text { Yang diperiksa }\end{array}$} & Satuan & Hasil & Persyaratan \\
\hline 1. & Berat jenis & $\mathrm{gr} / \mathrm{cm} 3$ & 1.1 & $>1$ \\
\hline 2. & Penetrasi & $(0.1 \mathrm{~mm})$ & 42 & Min. 40 \\
\hline 3. & Daktilitas & $\mathrm{Cm}$ & 81 & Min. 50 \\
\hline 4. & Titik lembek & ${ }^{0} \mathrm{C}$ & 56,5 & Min. 55 \\
\hline
\end{tabular}

\section{Hasil pemeriksaan gradasi}

Pemeriksaan gradasi agregat dilakukan pada agregat kasar dan agregat halus dengan menggunakan analisa saringan. Dari hasil pemeriksaan yang dilakukan dapat disimpulkan bahwa agregat tersebut tidak dapat digunakan langsung dalam campuran karena tidak memenuhi spesifikasi gradasi yang disyaratkan. Oleh karena itu, perlu dilakukan pencampuran antara dua fraksi tersebut. Koefisien campuran untuk fraksi kasar adalah 0,65 dan koefiesien campuran untuk fraksi agregat halus adalah 0,35. Dari hasil pencampuran dua fraksi tersebut, sudah memenuhi persyaratan untuk gradasi campuran beton aspal AC-BC. Pada pembuatan benda uji dalam penelitian ini, gradasi campuran antara agregat kasar dan agregat halus tidak digunakan 
dikarenakan kemungkinan terjadi perbedaan antara gradasi benda uji yang satu dengan yang lainnya. Untuk menjaga kesamaan gradasi keseluruhan benda uji, maka gradasi yang digunakan ditentukan dengan mengambil distribusi butiran lolos yang masih memenuhi spesifikasi gradasi yang disyaratkan.

\section{Hasil pengujian Marshall untuk penentuan kadar aspal optimum (KAO)}

Hasil pengujian Marshall menghasilkan parameter-parameter Marshall yaitu: density, stabilitas, flow, VIM , VMA, VFB dan Marshall quotient. Dari hasil pengujian Marshall dengan variasi kadar aspal Retona Blend 55 menggunakan gradasi rencana awal, setelah dianalisa dari parameter Marshall tidak bisa diperoleh nilai kadar aspal optimum (KAO), disebabkan adanya parameter Marshall yang tidak memenuhi persyaratan, terutama nilai stabilitas yang tidak mencapai $1.000 \mathrm{~kg}$. Penelitian selanjutnya adalah dengan mengubah gradasi untuk pembuatan benda uji selanjutnya. Hasil pengujian Marshall dengan variasi kadar aspal selanjutnya digambarkan pada suatu grafik hubungan antara kadar aspal dengan parameter Marshall. Rekapitulasi hasil pengujian Marshall untuk variasi kadar aspal menggunakan gradasi rencana awal disajikan pada Tabel 5.

Tabel 5 Rekapitulasi Hasil Pengujian Marshall dengan Variasi Kadar Aspal dengan Gradasi Rencana Awal

\begin{tabular}{|c|c|c|c|c|c|c|c|}
\hline \multirow{2}{*}{ No } & \multirow{2}{*}{$\begin{array}{c}\text { Karakteristik } \\
\text { Campuran }\end{array}$} & \multicolumn{5}{|c|}{ Kadar Aspal (\%) } & Spesifikasi \\
\cline { 3 - 7 } & & $\mathbf{4 , 5}$ & $\mathbf{5 , 0}$ & $\mathbf{5 , 5}$ & $\mathbf{6 , 0}$ & $\mathbf{6 , 5}$ & \\
\hline 1. & Stabilitas $(\mathrm{kg})$ & 819,14 & 1044,93 & 1409,74 & 1867,95 & 1830,56 & $\geq 1000$ \\
\hline 2. & Flow Plastis $(\mathrm{mm})$ & 5,8 & 6,5 & 6,0 & 5,6 & 6,0 & $3-6$ \\
\hline 3. & $M Q(\mathrm{Kg})$ & 140,41 & 160,87 & 243,62 & 336,78 & 306,83 & $\geq 300$ \\
\hline 4. & Density $(\mathrm{gr} / \mathrm{cm} 3)$ & 2,08 & 2,10 & 2,14 & 2,21 & 2,2 & $\geq 2$ \\
\hline 5. & VIM $(\%)$ & 12,50 & 11,37 & 8,95 & 5,38 & 5,37 & $3,5-5,5$ \\
\hline 6. & $V M A(\%)$ & 21,03 & 20,91 & 19,66 & 17,45 & 18,37 & $\geq 15$ \\
\hline 7. & $V F B(\%)$ & 40,56 & 45,65 & 54,51 & 69,17 & 70,77 & $\geq 65$ \\
\hline
\end{tabular}

\section{Hasil pengujian Marshall pada KAO}

Dari pengujian beberapa komposisi campuran maka didapatkan hasil terbaik adalah dengan komposisi campuran dengan menggunakan filler 4,5\% abu sabut kelapa dan kadar aspal optimum pada $6,25 \%$. Hasil pengujian dan perhitungan parameter Marshall aspal Retona Blend dengan pencampuran abu sabut kelapa lebih lengkapnya disajikan pada pada Tabel 6 di bawah ini dan penentuan Kadar Aspal Optimal ditampilkan pada Gambar 1. 
Tabel 6 Hasil Pengujian Marshall pada Kadar Aspal Optimum 6.25\%

\begin{tabular}{|c|c|c|c|}
\hline No & $\begin{array}{c}\text { Karakteristik } \\
\text { Campuran }\end{array}$ & $\begin{array}{c}\text { Kadar Aspal Optimum } \\
\mathbf{6 , 2 5 \%}\end{array}$ & Spesifikasi Dept. PU \\
\hline 1. & Stabilitas (kg) & 1295,47 & $\geq 1000$ \\
\hline 2. & Flow Plastis (mm) & 4,0 & $3-6$ \\
\hline 3. & $M Q(K g)$ & 328,51 & $\geq 300$ \\
\hline 4. & Density $(\mathrm{gr} / \mathrm{cm} 3)$ & 2,21 & $\geq 2$ \\
\hline 5. & VIM $(\%)$ & 5,34 & $3,5-5,5$ \\
\hline 6. & $V M A(\%)$ & 17,89 & $\geq 15$ \\
\hline 7. & $V F B(\%)$ & 70,17 & $\geq 65$ \\
\hline
\end{tabular}

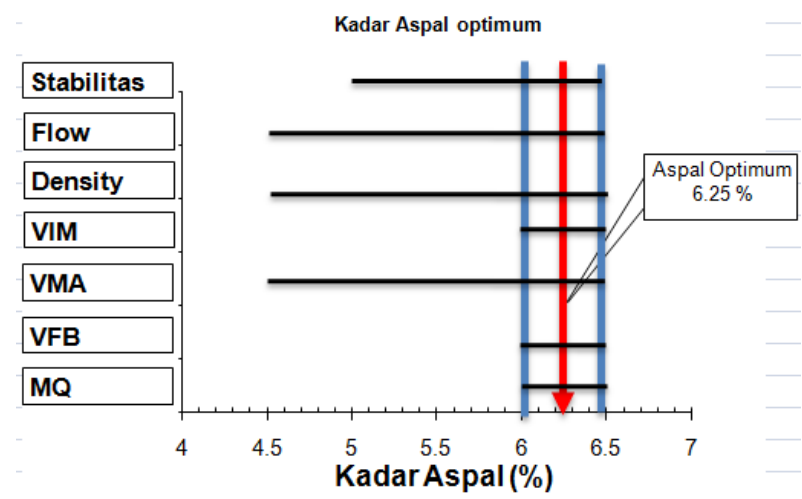

\section{Hasil Analisis Regresi Parameter Marshall}

Gambar 1. Penentuan Kadar Aspal Optimum

Hubungan antara kadar aspal dengan parameter Marshall dianalisa dengan analisa regresi. Analisa regresi yang digunakan yaitu analisa regresi yang sesuai dengan bentuk penyebaran data yang membentuk suatu garis lengkung atau lurus (linear). Dalam hal ini, regresi nonlinier dianggap paling sesuai untuk penyebaran data dengan bantuan software Microsoft Excell. Berikut grafik hubungan antara kadar aspal dengan parameter Marshall yang meliputi hubungan stabilitas dengan kadar aspal, hubungan flow dengan kadar aspal, hubungan VMA dengan kadar aspal, hubungan Marshall Quotient dengan kadar aspal, hubungan VIM dengan kadar aspal, dan hubungan VFB dengan kadar aspal.
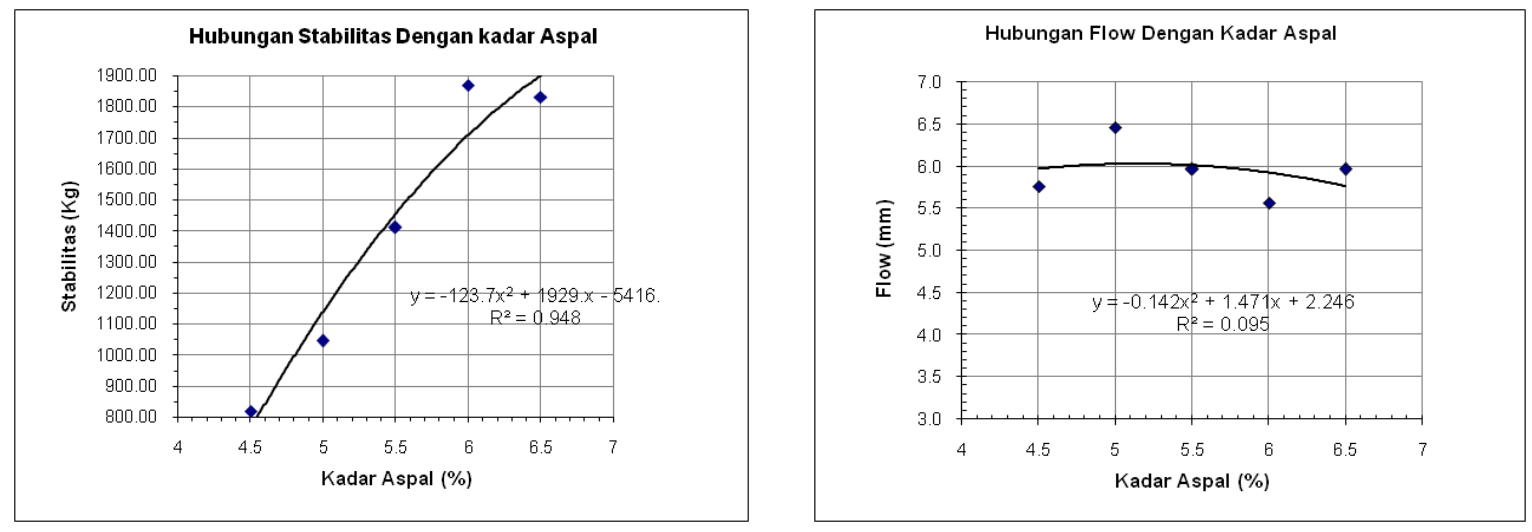

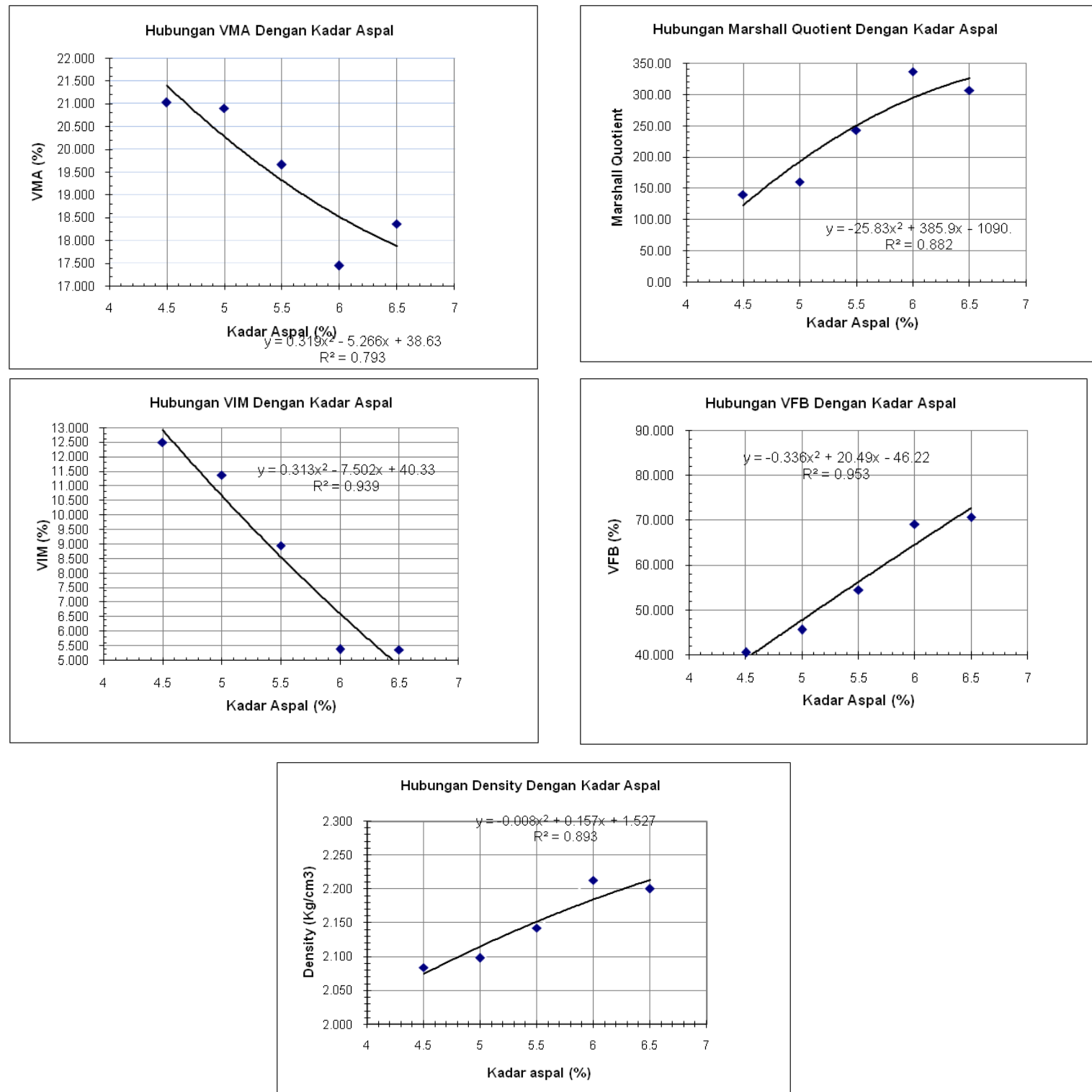

Gambar 2. Hubungan Kadar Aspal dengan beberapa parameter Marshall

\section{KESIMPULAN}

Dari hasil penelitian yang telah dilakukan, maka dapat diambil beberapa kesimpulan sebagai berikut.

1. Sifat-sifat fisis agregat yang telah diperiksa di laboratorium diperoleh bahwa sebagian besar sifat fisis tersebut telah memenuhi persyaratan spesifikasi yang ditentukan, kecuali indeks kelonjongan dan kepipihan tidak dapat memenuhi spesifikasi, yaitu maksimal $10 \%$.

2. Pemeriksaan sifat-sifat fisis aspal Retona Blend 55 yang meliputi pemeriksaan berat jenis, penetrasi, daktilitas, dan titik lembek menunjukkan bahwa aspal tersebut dapat digunakan karena memenuhi persyaratan yang ditetapkan. 
3. Komposisi campuran yang memperoleh hasil terbaik adalah dengan komposisi campuran dengan menggunakan abu sabut kelapa sebagai filler 4,5\% dan kadar aspal optimum pada $6,25 \%$.

\section{SARAN}

Berdasarkan hasil penelitian, diusulkan beberapa saran sebagai berikut.

1. Secara teknis hasil pengujian campuran aspal Retona Blend yang menggunakan filler dari $1 \%$ abu sabut kelapa dapat direkomendasi untuk pembuatan jalan kolektor.

2. Perlu dilakukan analisis lebih lanjut tentang penggunaan abu sabut kelapa sebagai filler pada jenis aspal pen 60/70 dan aspal lainnya sebagai pembanding, sehingga dapat diketahui kinerja kemampuan jenis aspal mana yang lebih baik digunakan pada kondisi tertentu.

\section{DAFTAR PUSTAKA}

[1] Anonim, 2004, Pedoman Pekerjaan Campuran Beraspal Panas, Direktorat Jenderal Bina Marga, Departemen PU, Jakarta.

[2] Badan Pusat Statistik (BPS). Aceh dalam Angka 2014. BPS Provinsi Aceh.

[3] Direktorat Jenderal Bina Marga, 2010, Dokumen Pelelangan Nasional Penyediaan Pekerjaan Konstruksi, Penerbit Direktorat Jenderal Bina Marga.

[4] Direktorat Jenderal Perkebunan Statistik Perkebunan Kelapa Indonesia, 2014, Tree Crop Estate Statistics of Indonesia 2013-2015, Penerbit Direktorat Jenderal Perkebunan, Jakarta.

[5] Sukirman, S., 2003, Beton Aspal Campuran Panas, Granit, Jakarta.

[6] Palungkun, R., 2004, Aneka Produk Olahan Kelapa, Penebar Swadaya, Jakarta.

[7] Suprapto, TM., 2006, Bahan dan Struktur Jalan Raya, Yogyakarta, KMTS Teknik sipil Universitas Gadjah Mada.

[8] Zulfikar, Saleh, S.M., dan Anggraini, R., 2014. Tinjauan Penggunaan Serbuk Arang Tempurung Kelapa sebagai Filler Terhadap Karakteristik Laston Lapis Aus (AC-WC). Jurnal Teknik Sipil Pascasarjana Universitas Syiah Kuala, Vol. 3, No. 2, Mei 2014. ISSN: 2302-0253, pp: 149-157. 